\title{
THE INFLUENCE OF SUCRALOSE ON THYROID GLAND FUNCTION
}

\section{WPEYW SUKRALOZY NA STAN FUNKCJONALNY GRUCZOŁU TARCZYCY}

\author{
Oleksandr Oliynyk $\mathbf{k}^{1(\mathrm{~A}, \mathrm{~B}, \mathrm{C}, \mathrm{D}, \mathrm{E}, \mathrm{F}, \mathrm{G})}$
}

${ }^{1}$ Department of Medical Rescue, Pope John Paul II State School of Higher Education in Biała Podlaska, Poland

Authors' contribution Wkład autorów: A. Study design/planning zaplanowanie badań B. Data collection/entry zebranie danych C. Data analysis/statistics dane - analiza i statystyki D. Data interpretation interpretacja danych E. Preparation of manuscript przygotowanie artykułu F. Literature analysis/search wyszukiwanie i analiza literatury G. Funds collection zebranie funduszy

Tables: 1

Figures: 0

References: 19

Submitted: 2020 Jun 9

Accepted: 2020 Aug 3

\section{Summary}

Background. Recently, an increasing number of scientific studies have reported on the adverse effects of sweeteners on the body. The aim of this work was to study the effect of sucralose on the production of thyroid hormones.

Material and methods. The study involved 30 women (average age $24.5 \pm 5.2$ years) who considered themselves to be healthy. Blood levels of free and total triiodothyronine, free and total thyroxine, as well as thyroid-stimulating hormone were determined. The women were then prescribed sucralose for a month, taken daily at a dose of $15 \mathrm{mg} / \mathrm{kg}$. At the end of this period, levels of thyroid hormones were measured again.

Results. After the sucralose regimen, free and total triiodothyronine and total thyroxine were found to be 2.0, 1.58 and 1.46 times lower, respectively, than before sucralose intake $(\mathrm{P}<0.001)$. Conclusions. Given that sucralose affects the production of thyroid hormones, it can be concluded that sucralose is not a biologically inert compound.

Keywords: thyroid hormones, thyroid gland, sucralose

\section{Streszczenie}

Wprowadzenie. W ostatnim czasie coraz więcej badań naukowych porusza kwestię szkodliwego wpływu słodzików na organizm. Celem niniejszej pracy było przebadanie związku sukralozy z produkcją hormonów tarczycowych.

Materiał i metody. Badanie objęło 30 kobiet (średnia wieku 24,5ะ5,2 roku), które określiły siebie jako zdrowe. Ustalono poziomy wolnej i całkowitej trijodotyroniny, wolnej i całkowitej tyroksyny oraz hormonu stymulującego hormon tarczycy we krwi. Następnie zalecono pacjentkom przyjmowanie sukralozy codziennie przez miesiąc (w dawce $15 \mathrm{mg} / \mathrm{kg}$ ). Po tym okresie ponownie zbadano wartości hormonów tarczycy.

Wyniki. Po reżimie dawkowania sukralozy, zaobserwowano znaczący spadek wolnej i całkowitej trijodotoroniny oraz całkowitej tyroksyny o odpowiednio 2,0, 1,58 i 1,46 $(\mathrm{P}<0,001)$. Wnioski. Wziąwszy pod uwagę fakt, iż sukraloza wpływa na produkcję hormonów tarczycy, można stwierdzić, że nie jest ona związkiem biologicznie obojętnym.

Słowa kluczowe: hormony tarczycy, gruczoł tarczycy, sukraloza

\section{Introduction}

The use of artificial sweeteners in food is becoming increasingly problematic due to their potential impact on consumer health. They are introduced into many food products, and many people consume these ingredients without even knowing it. In addition, many artificial sweeteners have been identified as environmental pollutants and can be found in groundwater and groundwater aquifers [1]. At present, there is still no consensus on the health effects of artificial sweeteners. Consumption of artificial sweeteners has been associated with health problems such as cancer, weight gain, metabolic disorders, type 2 diabetes, and changes in the composition of the intestinal microbiota.

Thyroid hormones are essential for the normal functioning of many organs and body systems. Thyroid function is controlled by dynamic interrelations between the hypothalamus, pituitary gland, and thyroid. These interactions are realized through various mechanisms including metabolism and the transport of thyroid hormones. There are also some environmental chemical substances that are capable of suppressing thyroid function (i.e.endocrine disrupting chemicals, EDC) by adversely affecting hormone production by the gland. These substances are called thyroid toxicants and include a wide range of chemical structures that act through various mechanisms. Many environmental pollutants act as toxicants and can also be called thyroid destroying agents. In the broad sense, these substances change regulatory enzymes involved in thyroid hormone homeostasis. Recently, the issue of thyroid toxicants has drawn considerable attention as increasing experimental evidence Sidorska 95/97, 21-500 Biała Podlaska, Poalnd, e-mail: alexanderoliynyk8@gmail.com, phone: +48 83 344 99 00, 0RCID: https://orcid.org/0000-0003-2886-7741 Copyright: (C) Pope John Paul II State School of Higher Education in Biała Podlaska, Oleksandr Oliynyk. This is an Open Access journal, all articles are distributed under the terms of the Creative Commons Attribution-NonCommercial-ShareAlike 4.0 International (CC BY-NC-SA 4.0) License (http://creativecommons.org/licenses/by-nc-sa/4.0/), allowing third parties to copy and redistribute the material in any medium or format and to remix, transform, and build upon the material, provided the original work is properly cited and states its license. 
has shown that some seemingly inert substances can be harmful to the thyroid. However, extrapolation of experimental findings in animals to humans is restrained by the relatively unknown mechanisms of the toxicants' actions in any organism, and which may differ across species. Substances that are routinely used as food additives, sweeteners in particular, have been found to possess toxicant characteristics [2]. The influence of some food sweeteners on the activity of thyroid hormones has only been studied experimentally, with their effects on human metabolism not having been investigated thoroughly thus far. The objective of this study was to examine the effect of sucralose, a widely used sugar substitute, on thyroid functional state with respect to production of thyroid hormones.

\section{Material and methods}

The study involved 50 Polish women with an average age of 24.5 (95\% CI 19.2 to 28.4), who were residents of Lublin province and Biała Podlaska district, Poland, without concomitant diseases and who estimated themselves to be healthy. The blood content of free and general triiodothyronine (T3) - FT3 and T3, respectively - and free and general thyroxine (T4), FT4 and T4 respectively, as well as thyrotropic hormone (TSH) were determined [3]. Thereafter, the women were given StarkPharm sucralose to be taken orally in powder form for a month daily at a dose of $15 \mathrm{mg} / \mathrm{kg}$, which is regarded as the maximum allowable dose according to EDQM (European Directorate for the Quality of Medicines \& Health Care) recommendations [4]. When dosing sucralose powder, it was assumed that $1 \mathrm{~cm}^{3}$ contains $350 \mathrm{mg}$ of sucralose. After one month, the blood levels of all of the hormones mentioned were tested again. Statistical analysis included calculation of mean arithmetic values (M) and standard deviation (SD). The data was tested for normal distribution using the Shapiro-Wilk test. For source data with normal distribution, Student t-distribution was used to determine statistical significance of different mean values. Statistical significance was calculated to be $\mathrm{P}<0.001$. Microsoft Excel 2010 and StatSoft STATISTICA 10 programs were used for the calculations. The research was financed by a grant from Pope John Paul II State School of Higher Education, Biała Podlaska and approved by the Bioethics committee of the school.

\section{Results}

We observed 2.0, 1.58 and 1.46 fold $(\mathrm{P}<0.001)$ decreases in the blood content of FT3, T3 and T4, respectively, after sucralose intake in comparison to their values prior to the use of sucralose. After taking sucralose, TSH levels were 4.41 times $(\mathrm{P}<0.001)$ higher than before sucralose use. Though the changes were significant, levels of the thyroid hormones and TSH were found to be within the limits of their respective normal ranges. Therefore, despite significant decreases in the amounts of the thyroid hormones after sucralose intake, the state of the thyroid could not be characterized as subclinical hypothyroidism. The symptoms of impaired thyroid functional state in the women under examination after taking sucralose were not found either.

It is worth noting that impaired thyroid function is among the most common human pathologies, its prevalence varying regionally and depending primarily on iodine intake. Impairment of thyroid function is divided into manifest and subclinical forms [5]. Manifest forms are characterized by changing levels of both TSH and thyroid hormones, while subclinical forms reveal changes only in TSH, with levels of thyroid hormones remaining normal.

Table 1. Blood content of thyroid hormones in the women examined prior to, and after sucralose intake

\begin{tabular}{|c|c|c|}
\hline Thyroid hormones & $\begin{array}{c}\text { Baseline } \\
(\mathbf{n = 5 0 )}\end{array}$ & $\begin{array}{c}\text { After sucralose intake } \\
\mathbf{( n = 5 0 )}\end{array}$ \\
\hline $\mathrm{TSH}, \mathrm{mIU} / \mathrm{L}$ & $1.25 \pm 0.50$ & $5.52 \pm 2.77^{*}$ \\
\hline $\mathrm{FT} 3, \mathrm{pg} / \mathrm{mL}$ & $3.16 \pm 0.40$ & $1.56 \pm 0.35^{*}$ \\
\hline $\mathrm{FT} 4, \mathrm{ng} / \mathrm{dL}$ & $1.10 \pm 0.19$ & $0.81 \pm 0.22$ \\
\hline $\mathrm{T} 3, \mathrm{ng} / \mathrm{dL}$ & $101.54 \pm 13.96$ & $64.45 \pm 8.47^{*}$ \\
\hline $\mathrm{T} 4, \mathrm{ng} / \mathrm{dL}$ & $7.47 \pm 1.28$ & $5.13 \pm 0.65^{*}$ \\
\hline
\end{tabular}

Notes: *Significant difference compared to levels before sucralose intake $(\mathrm{P}<0.001)$.

\section{Discussion}

Manifest hypothyroidism has been found to cause numerous abnormalities in various organs and systems, some of which include enhanced fatigability, edemas, constipation, cognitive disturbances, menstrual disorders, paresthesia, bradycardia, dyslipidemia, etc. Subclinical hypothyroidism can reveal itself through numerous 
and nonspecific symptoms, similar to those in manifest hypothyroidism, although there may also be a lack of any symptoms. Subclinical hypothyroidism is an independent risk factor for atherosclerosis and myocardial infarction [5]. Subclinical thyroid abnormalities are more prevalent than manifest ones. Functional thyroid disorders are more frequent in areas with inadequate iodine intake. It is noteworthy that Biała Podlaska, the site of the research study, is endemic with respect to iodine deficiency, with manifest hypothyroidism found in 0.2 $2 \%$, and subclinical hypothyroidism in $8-10 \%$ of the population [6]. Prevalence of hyperthyroidism increases with age and is higher in Caucasians than in people of other races. High risk groups for the development of thyroid abnormalities include postpartum women and the elderly.

Intake of toxicants may lead to various disorders in the functional state of the thyroid. Endocrine abnormalities owing to the effects of thyroid toxicants are commonly associated with a wide range of adverse consequences. Prototype thyroid toxicants, such as dioxins, polychlorinated diphenyls, and polybrominated diphenyl ethers have been proven to change thyroid hormonal homeostasis, mainly through activation of their hepatic catabolism $[7,8]$.

Our findings confirm the results of Pałkowska-Goździk et al. who studied thyroid functional state in albino rats after three-week sucralose intake. The authors found that sucralose intake changed thyroid peroxidase activity and led to reduced synthesis of thyroid hormones - changes in the peripheral metabolism of thyroid hormones has been suggested as a possible cause of this [9]. It was concluded that sucralose is metabolically active and capable of aggravating metabolic disorders by adversely affecting thyroid hormone metabolism.

Sachmechi et al. [10] described a clinical case of the development of autoimmune hypothyroidism in a woman taking sucralose. The connection between Hashimoto's disease and excessive consumption of sugar substitutes was demonstrated by a rapid return to normal levels of thyroid hormones and thyroid antibodies after sucralose was discontinued.

These data, alongside our findings, challenge the existing perception of sucralose being absolutely harmless. Sucralose (trichloro galacto saccharose, $\mathrm{C}_{12} \mathrm{H}_{19} \mathrm{C}_{13} \mathrm{O}_{8}$ ), is a low calorie sweetener used in a wide range of foodstuffs and drinks. As a universal sweetener, sucralose was approved by the US FDA (Food and Drug Administration) in 1999 and by the EFSA (European Food Safety Authority) in 2004. In addition, the recommendation that sucralose should be used as a food additive was approved by the EDQM (European Directorate for the Quality of Medicines \& Health Care) on July 2, 2010 [11]. Until a few years ago, the sweetener was regarded as absolutely safe. However, in the past few years, the idea of sucralose being absolutely non-toxic has somewhat changed.

Sucralose intake in rats has been shown to increase expression of P-glycoprotein (P-gp) efflux transporter and two cytochrome P450 (CYP) isoenzymes in the intestine [12]. P-gp and CYP are key components of presystemic detoxification, which is involved in drug metabolism. Sucralose has also been shown to change microbial composition in the gastrointestinal tract (GIT) with significant decreases in the amount of beneficial or 'good' bacteria in the gut. Although early research asserted that sucralose passes through the GIT unchanged, subsequent studies have revealed that a portion of the sweetener is actually metabolized in the GIT, as evidenced by numerous peaks found in thin-layer radiochromatographic profiles of fecal methanol extracts after peroral sucralose intake [12]. At present, the identity and safety profile of sucralose metabolites are unknown.

Sucralose intake has been found to change the intestinal microbiome [13], which plays a key role in processes such as gastrointestinal digestion and fermentation, immune cell development, and regulation of the enteric nervous system. Inflammation is a common consequence of intestinal microbiome dysbiosis. Bian et al. [14] studied the structural and functional effects of sucralose on the intestinal microbiota and associated inflammation. In the study, C57BL/6 male mice were given sucralose in drinking water for 6 months. Differences in the composition of the intestinal microbiota and metabolites in control mice, versus those given sucralose were determined using excretion of 16S rRNA genes, analysis of gene functional enrichment, and metabolomics. Expression of inflammation-related genes in intestinal tissue was also analyzed. It was found that sucralose affects the intestinal microbiota and the dynamics of its changes. Enrichment of bacterial pro-inflammatory genes and abnormalities in fecal metabolites were observed and suggest that daily intake of sucralose (15 $\mathrm{mg} / \mathrm{kg}$ ) for a prolonged period of time (6 months in the study) is fraught with the risk of tissue inflammation associated with disruption of the intestinal microbiota. These findings emphasize the role of sucralose in the intestinal microbiome in the regulation of processes that particularly include chronic inflammation.

In a study by Harpaz et al. [15], the relative toxicity of sucralose in relation to intestinal microbiota was tested using genetically modified bioluminescent $E$. coli bacteria. Toxic effects associated with sucralose were observed after consumption of doses higher than recommended.

There is not much data on the toxic effects of sucralose. According to studies by Magnuson et al. [16], sucralose affects the general glycemic profile only at doses higher than those recommended for use. They also found that sucralose affects sweet taste receptors in the intestine. Moreover, human and rodent studies have shown that 
sucralose can induce changes in levels of glucose, insulin, and glucagon-like peptide 1 (GLP-1) [17]. Additionally, sucralose, and a product of its hydrolysis, have been found to be mutagenic at high concentrations [18].

Long-term sucralose consumption can also affect cognitive function as it has been shown to significantly worsen passive avoidance learning test (PAL) scores [12]. Excessive use of sucralose has harmful effects on cognitive functions and the integrity of the hippocampus in rats [19]. Prolonged sucralose intake has been shown to cause a significant decrease in the number of neurons in the CA1-CA3 areas of the rat hippocampus. Increased lipid peroxidation processes in the brain have also been seen.

Increased cytochrome P450 metabolic activity in response to high amounts of sucralose can lead to accelerated excretion of hormones and bile, as reported by Crofton et al. [8], and may be a possible mechanism underlying our findings in this study of sucralose-induced decreases in thyroid hormone content in the blood.

Thus, our findings of increased sucralose intake leading to reductions in circulating thyroid hormones, agree with data from other studies which show that sucralose is not a biologically inert substance. This should be carefully considered when evaluating its potential effect on patients with endocrine pathologies.

\section{Conclusions}

Daily intake of sucralose for a month leads to significant decreases in the blood content of thyroid hormones, namely free and general triiodothyronine, and general thyroxine, along with a significant increase in thyrotropic hormone in young, healthy women.

\section{References:}

1. Vamanu E, Pelinescu D, Gatea F. Altered in vitro metabolomic response of the human microbiota to sweeteners. Genes (Basel). 2019 Jul 15; 10(7): E535. https://doi.org/10.3390/genes10070535

2. Zoeller TR. Environmental chemicals targeting thyroid. Hormones (Athens). 2010; 9(1): 28-40. https://doi.org/10.14310/horm.2002.1250

3. Sapin R, Schlienger JL. Thyroxine (T4) and tri-iodothyronine (T3) determinations: techniques and value in the assessment of thyroid function. Ann Biol Clin (Paris). 2003; 61(4): 411-20.

4. European Pharmacopoeia. Supplement 10.1. Strasbourg: European Directorate for the Quality of Medicines \& HealthCare; 2019.

5. National Institute of Diabetes and Digestive and Kidney Diseases. Hypothyroidism [Internet]. Bethesda: National Institute of Diabetes and Digestive and Kidney Diseases; 2013 [cited 2016 March 5]. Available from: https://www.niddk.nih.gov/health-information/endocrine-diseases/hypothyroidism

6. Udovcic M, Pena R, Patham B. Hypothyroidism and the heart. Methodist Debakey Cardiovasc J. 2017; 13(2): 55-59. https://doi.org/10.14797/mdcj-13-2-55

7. Crofton KM. Thyroid disrupting chemicals: mechanisms and mixtures. Int J Androl. 2008; 31(2): 209-223. https://doi.org/10.1111/j.1365-2605.2007.00857.x

8. Crofton KM, Craft ES, Hedge JM. Thyroid-hormone-disrupting chemicals: evidence for dose-dependent additivity or synergism. Environ Health Perspect. 2005; 113(11): 1549-54. https://doi.org/10.1289/ehp.8195

9. Pałkowska-Goździk E, Bigos A, Rosołowska-Huszcz D. Type of sweet flavour carrier affects thyroid axis activity in male rats. Eur J Nutr. 2018; 57(2): 773-782. https://doi.org/10.1007/s00394-016-1367-x

10. Sachmechi I, Khalid A, Awan S. Autoimmune thyroiditis with hypothyroidism induced by sugar substitutes. Cureus. 2018; 10(9): e3268. https://doi.org/10.7759/cureus.3268

11. Ford HE, Peters V, Martin NM. Effects of oral ingestion of sucralose on gut hormone response and appetite in healthy normal-weight subjects. Eur J Clin Nutr. 2011; 65(4): 508-513. https://doi.org/10.1038/ejcn.2010.291

12. Schiffman SS, Rother KI. Sucralose, a synthetic organochlorine sweetener: overview of biological issues. J Toxicol Environ Health B Crit Rev. 2013; 16(7): 399-451. https://doi.org/10.1080/10937404.2013.842523

13. Ramírez-Durán N, Valdés-Ramos R, Mondragón-Velásquez T. Chronic consumption of sweeteners and its effect on glycaemia, cytokines, hormones, and lymphocytes of GALT in CD1 mice. Biomed Res Int. 2018; 2018: 1345282. https://doi.org/10.1155/2018/1345282

14. Bian X, Chi L, Gao B. Gut microbiome response to sucralose and its potential role in inducingliver inflammation in mice. Front Physiol. 2017; 8: 487. https://doi.org/10.3389/fphys.2017.00487

15. Harpaz D, Yeo LP, Cecchini F. Measuring artificial sweeteners toxicity using a bioluminescent bacterial panel. Molecules. 2018; 23(10): 2454. https://doi.org/10.3390/molecules23102454

16. Magnuson BA, Roberts A, Nestmann ER. Critical review of the current literature on the safety of sucralose food. Chem Toxicol. 2017; 106(Pt A): 324-355. https://doi.org/10.1016/j.fct.2017.05.047 
17. Wong H, Lehman-McKeeman LD, Grubb MF. Increased hepatobiliary clearance of unconjugated thyroxine determines DMP 904-induced alterations in thyroid hormone homeostasis in rats. Toxicol Sci. 2005; 84(2): 232-242. https://doi.org/10.1093/toxsci/kfi094

18. Gómez-Arauz AY, Bueno-Hernández N, Palomera LF. A Single $48 \mathrm{mg}$ sucralose sip unbalances monocyte subpopulations and stimulates insulin secretion in healthy young adults. J Immunol Res. 2019 Apr 28; 2019: 6105059. https://doi.org/10.1155/2019/6105059

19. Erbaş O, Erdoğan M, Khalilnezhad A. Evaluation of long-term effects of artificial sweeteners on rat brain: a biochemical, behavioral, and histological study. J Biochem Mol Toxicol. 2018; 32(6): e22053.

https://doi.org/10.1002/jbt.22053 